\title{
PENGELOLAAN KOMPLAIN (KELUHAN) MASYARAKAT DALAM MEWUJUDKAN PEMERINTAHAN YANG BAIK DI KOTA SEMARANG
}

\author{
Wiyanto \\ Fakultas Ekonomi, Universitas Pamulang \\ dosen01840@unpam.ac.id
}

\begin{abstract}
The purpose of this study is to find out the problems that cause complaints, complaints management of society and business undertaken Semarang city government to overcome obstacles in the management of community complaints in an attempt to realize good government in the city of Semarang. This research is a qualitative research. The research location is centered on Public Service Complaint Handling Center (P5) Semarang City. The source of data comes from the indep interviews conducted with employees P5, documents and questionnaires. Data were collected through interviews, documentation, and observation. To ensure the validity of the data the researchers used triangulation techniques and then performed the analysis. The results of this study indicate that the problem that raises the complaints in the community is the service both services and non services from service providers (government of Semarang City) not in accordance with community expectations. In addition, complaints arise due to service providers and service users who violate the rights of other service users. Model of community resolving as outcome of this research. Sugestion for government officials need to pay attention and support the community to improve the services provided. For the next researchess who conduct an integrated academic study of various disciplines.
\end{abstract}

Keywords: management, complaints, public service, good governance

\footnotetext{
Jurnal Pendidikan Kewarganegaraan

Journal of Civics and Education Studies

The journal is published by Department of Civic Education

Faculty of Teacher Training and Education

Universitas Pamulang - Indonesia

Copyright $\odot 2017 \mid$ ISSN: 2302-0865
} 


\section{PENDAHULUAN}

Dalam kehidupan bernegara Indonesia yang mengisyaratkan adanya amanat agar kesejahteraan untuk khalayak ramai, negara berkewajiban melayani setiap warga negara (citizen) demi tercapainya kebutuhan yang diinginkan oleh setiap warganya. Selain negara yang berbentuk republik, Indonesia merupakan sebuah negara yang demokratis, rakyat (demos) pada dasarnya adalah pemegang kekuasaan tertinggi (cratein). Karena demokrasi adalah governance of the people (pemerintahan dari rakyat), governance by people (pemerintahan oleh rakyat) dan governance for people (pemerintahan untuk rakyat) (Dede Rosyada, 2005 : 111). Sehingga kepentingan rakyat lebih diutamakan daripada kepentingan Negara.

Pemerintah sebagai pemegang mandat dari masyarakat dalam penyelenggaraan pelayanan publik, diharapkan dapat memberikan pelayanan kepada masyarakat yang lebih baik dan demokratis. Pemerintah dalam memberikan pelayanan harus dilakukan sesuai dengan harapan dan tuntutan warga negara. Pemerintah dalam memberikan pelayanan kepada masyarakat harus dipandang sebagai hak yang harus diperoleh oleh setiap warga negara.

Hak yang harus diperoleh masyarakat diantaranya adalah seperti yang tertuang pada pasal 28 Undang-Undang Dasar Negara Republik Indonesia (NKRI) Tahun 1945 bahwa ".........mengeluarkan pikiran dengan lisan dan tulisan dan sebagainya ditetapkan dengan undang-undang".
Undang-Undang Dasar Negara Republik Indonesia Tahun 1945 Pasal 28 F bahwa: "Setiap orang berhak untuk berkomunikasi dan memperoleh informasi untuk mengembangkan pribadi dan lingkungan sosialnya, serta berhak untuk mencari, memperoleh, memiliki, menyimpan, mengolah, dan menyampaikan informasi dengan menggunakan segala jenis saluran yang tersedia", merupakan hak yang dijamin oleh negara kepada setiap warga negara di samping hak-hak yang lain. Salah satu wujud hak yang harus diperoleh masyarakat adalah diberinya ruang untuk mengeluarkan pikiran dengan lisan dan tulisan dan sebagainya, dalam hal ini adalah komplain (keluhan) atas penyelenggaraan pelayanan publik yang diberikan oleh pemerintah. Karena dipandang sebagai hak maka harus didasarkan pada norma-norma hukum yang mengatur secara jelas.

Upaya memperbaiki pelayanan sebenarnya telah sejak lama dilaksanakan oleh pemerintah. Menurut Schelling and Chris Topher, Ed (dalam Rahmayanty, 2010:101) pentingnya mengorganisir komplain karena pelanggan yang mengeluh adalah teman baik kami, karena mereka memberikan kesempatan kepada kami untuk meningkatkan pelayanan. Pemerintah dalam hal ini adalah orang yang diberi mandat oleh masyarakat sebagai penyedia pelayanan untuk memperbaiki pelayanannya perlu melakukan berbagai upaya diantaranya adalah penanganan komplain (keluhan) dari masyarakat. 
Dalam mengejar tujuan kadangkadang manusia berorientasi pada diri pribadi atau kelompok, tetapi ada juga yang berorientasi pada kepentingan orang banyak atau umum (Suyahmo, 2009:98). Agar terjadi keseimbangan, keselarasan antara pengguna layanan publik dan penyedia layanan publik harus dipandang memiliki kedudukan yang sama-sama pentingnya. Sehingga akan tercipta kesejahteraan dan kebahagiaan bersama. Pemerintah sebagai penyelenggara pemerintahan dan masyarakat sebagai pengguna layanan maka dalam penyelenggaraan pemerintahan, pemerintah memerlukan adanya input kemudian diolah kedalam suatu proses dan menghasilkan output.

Input dalam penyelenggaraan pemerintahan dalam rangka memperbaiki pelayanan kepada masyarakat salah satunya adalah berupa tuntutan-tuntutan atau komplain (keluhan) atas pelayanan yang diberikan oleh penyelenggara pemerintahan. Input dari masyarakat yang masuk tentu harus diproses agar diperoleh sebuah keputusan atau kebijakan yang lebih baik dari pada sebelumnya. Untuk itu, input dari masyarakat perlu diolah atau diproses dengan benar agar diperoleh kebijakan yang baik, benar dan tepat untuk semua masyarakat.

Kemudahan prosedur pelayanan yang meliputi persyaratan-persyaratan, kejelasan dan kepastian petugas yang melayani, kedisiplinan petugas, tanggungjawab petugas yang melayani, kemampuan petugas yang melayani, kecepatan pelayanan, rasa keadilan dalam mendapatkan pelayanan, keramahan dan kesopanan petugas dalam memberikan pelayanan, kewajaran biaya untuk mendapatkan pelayanan, kesesuaian biaya yang dibayarkan dengan biaya yang ditetapkan, ketepatan pelaksanaan dengan jadwal waktu pelayanan, kenyamanan ruang pelayanan dan keamanan menjadi dambaan pengguna pelayanan.

Selama ini penanganan komplain (keluhan) masyarakat khususnya di Kota Semarang masih belum maksimal. Sesuai dengan pengamatan penulis, di Kota Semarang pengaduan masyarakat hanya diberi "ruang" dalam bentuk Kotak pengaduan atau saran dan pesan singkat melalui SMS, dan lain-lain yang tidak diintegrasikan dalam sebuah mekanisme atau pengelolaan pengaduan yang efektif dan transparan.

Selain itu, masyarakat Kota Semarang belum dapat mengadukan secara langsung permasalahan utamanya yang berkaitan dengan pelayanan yang diberikan pemerintah, melihat perkembangan penanganan atas pengaduannya, dan memberi tanggapan atas penanganan pengaduannya dengan mudah dan biaya yang murah.

Berdasarkan data yang diperoleh peneliti keluhan dalam kurun waktu Januari sampai dengan Desember 2009 adalah 562 (lima ratus enam puluh dua). Jumlah keluhan yang terselesaikan sebesar 474 (empat ratus tujuh puluh empat) atau $84,34 \%$. Keluhan dalam kurun waktu Januari sampai dengan Desember 2010 adalah 718 aduan. Hasil akumulasi keluhan pada tahun 2009 sampai dengan tahun 2010 adalah 1280 aduan yang 
masuk di Pusat Penanganan Pengaduan Pelayanan Publik Kota Semarang.

Apabila keadaan di Kota Semarang seperti itu tidak ditangani dengan baik, benar dan tepat maka akan berdampak pada rasa keperpercayaan dan kesetiaan masyarakat terhadap penyelenggara pemerintahan akan menurun. Tanggap dan responsif terhadap pengaduan yang masuk, merupakan bagian yang sangat penting dalam pengelolaan pengaduan.

Kebutuhan akan informasi atau data yang berkaitan dengan pengaduan masyarakat tentang pelayanan di Kota Semarang dinilai sudah sangat mendesak, karena itu diperlukan sebuah sistem pengelolaan yang dapat menampung informasi atau data pengaduan dan terintegrasi dalam suatu sistem database.

Manajemen komplain (keluhan) merupakan penggabungan dari dua kata yaitu Manajemen dan komplain (keluhan). Manajemen komplain (keluhan) merupakan implementasi teori manajemen dalam bidang komplain (keluhan). Manajemen komplain mencakup empat pilar atau tahapan; Planning, yaitu perencanaan awal secara teratur dari setiap usaha untuk mencapai tujuan; Organizing, yaitu langkah kearah pelaksanaan rencana yang telah disusun sebelumnya (Planning);

Actuing, yaitu keseluruhan usaha, cara, teknik, dan metode untuk mendorong para anggota organisasi agar mau dan ikhlas bekerja dengan sebaik mungkin demi tercapainya tujuan organisasi dengan efisien, efektif, dan ekonomis (Siagian, 1992:128 dalam Sutomo, dkk, 2007:14); dan Controlling. Yaitu usaha yang didalamnya terkandung kegiatan perbaikan dan penyempurnaan sehingga pekerjaan atau kegiatan sesuai dengan rencana atau tujuan yang telah ditetapkan dalam planning. Kegiatan pengawasan sangat berkaitan erat dengan perencanaan. Dengan adanya pengawasan maka kegiatan yang telah mendapat perbaikan dan penyempurnaan ini akan menjadi feed back bagi perencanaan berikutnya. Sehingga dalam manajemen ini controlling sangat penting sekali untuk dilakukan dalam sebuah organisasi.

Manajemen komplain merupakan sebuah langkah untuk mengelola komplain-komplain dari masyarakat agar diperoleh sebuah hasil yang optimal yaitu hasil yang baik, benar, dan tepat yang bukan semata-mata untuk memudahkan kinerja penyelenggara pemerintah saja akan tetapi untuk masyarakat penerima atau pengguna layanan. Menurut Parasuraman, dkk (dalam Monier, 2001) kualitas jasa dipersepsikan baik apabila jasa yang diterima atau dirasakan sesuai dengan yang diharapkan. Ada lima faktor utama yang menentukan kualitas pelayanan, yaitu : Tangibles, Reliability, Responsivness, Assurance, dan Emphaty.

Saeful Arif (2008:3) pelayanan publik adalah suatu pelayanan atau pemberian kepada masyarakat yang berupa penggunaan fasilitas umum, baik jasa non jasa, yang dilakukan oleh organisasi publik.

Kebijakan publik merupakan rangkaian dari dua kata yakni kebijakan (Policy) dan publik. Kebijakan merupakan terjemahan dari kata Inggris policy artinya politik, siasat, kebijaksanaan 
(Wojowasito, 1975: 60, dalam I Wayan Suandi, 2010:11).

Good governance adalah tindakan atau tingkah laku yang didasarkan pada nilainilai yang bersifat mengarahkan, mengendalikan, atau mempengaruhi masalah publik untuk mewujudkan nilainilai itu dalam tindakan dan dalam kehidupan keseharian (Dede Rosyada, 2005:180). Dalam hal ini sebuah pemerintahan dikatakan baik jika produktif dan memperlihatkan hasil dengan indikator kemampuan ekonomi rakyat meningkat baik dalam aspek produktifitas maupun daya belinya , kesejahtraan spiritualnya terus meningkat dengan indikator rasa aman, tenang, dan bahagia serta sense of nationality dengan baik. ). Khandakar Qudrat-I Elahi (2009:1167) mengatakan bahwa "Good governance in turn hinges on politically trained intelligent and ethical individuals running public administration" (Pemerintahan yang baik dalam gilirannya bergantung pada individu yang cerdas dan etika individu dalam menjalankan administrasi publik).

Rumusan masalah yang akan dipecahkan dalam penelitian ini adalah; 1) apa saja persoalan yang menimbulkan komplain (keluhan), pengelolaan komplain masyarakat?; 2) bagaimanakah pengelolaan keluhan masyarakat dalam upayanya mewujudkan pemerintahan yang baik di kota semarang?; dan 3) apa usaha untuk mengatasi hambatan dalam pengelolaan keluhan masyarakat di kota semarang?

\section{METODE PENELITIAN}

Penelitian ini dilakukan dengan pendekatan deskriptif kualitatif, dimana data-data diperoleh akan dianalisis dan akan dideskripsikan secara kualitatif. Prosedur kualitatif menghasilkan penelitian yang menghasilkan data deskriptif berupa kata maupun makna, nilai serta pengertian dengan pendekatan yang diarahkan pada latar dan individu secara holistic 'utuh' atau memandangnya sebagai suatu kesatuan.

Dengan data kualitatif kita dapat mengikuti dan memahami perihal yang menyebabkan munculnya komplain (keluhan) masyarakat khususnya di Kota Semarang, pengelolaan komplain (keluhan) masyarakat oleh pemerintah Kota Semarang dan memperoleh penjelasan yang komprehensip dan bermanfaat.

Penelitian ini dilaksanakan pada kurun waktu 2009 sampai dengan 2010 di unit-unit pelayanan publik pada unit pelayanan pemerintah Kota Semarang. Namun, lokasi penelitian dipusatkan di pusat penanganan pengaduan pelayanan publik (P5) Kota Semarang yang beralamatkan di Jl. Pemuda No.148 Gedung Sekretariat lantai 1 Semarang dan pada dinas/instansi yang ada di bawah naungan POKJA (Kelompok Kerja) 1 sampai POKJA (Kelompok Kerja) 5 di P5 (Pusat Penanganan Pengaduan Pelayanan Publik) Kota Semarang.

Responden penelitian ini adalah pegawai yang bekerja di P5 (Pusat Penanganan Pengaduan Pelayanan Publik Kota Semarang) dan pegawai pada 
dinas/instansi yang ada dibawah naungan POKJA (Kelompok Kerja) 1 sampai POKJA (Kelompok Kerja) 5 di P5 (Pusat Penanganan Pengaduan Pelayanan Publik) Kota Semarang. Sehingga akan ditemukan perihal yang menyebabkan munculnya komplain, bagaimana pengelolaan komplain, apa usaha yang dilakukan untuk mengatasi hambatan dalam mengelola komplain.

Sumber data dalam penelitian ini diperoleh dari dua sumber yakni sumber primer dan sumber skunder. Pengumpulan data menggunakan 3 (Tiga) metode pokok yang saling berkaitan dan melengkapi, yaitu; (1) Metode Wawancara. Wawancara yang digunakan dalam penelitian ini adalah Indep Interview (wawancara mendalam) yang dilakukan dengan pegawai-pegawai yang bekerja di pusat penanganan pengaduan pelayanan publik (P5) Kota semarang dan pegawaipegawai berada di bawah naungan POKJA (Kelompok Kerja) 1 sampai POKJA (Kelompok Kerja) 5 di P5 (Pusat Penanganan Pengaduan Pelayanan Publik) Kota Semarang. Wawancara digunakan untuk mengungkap informasi tentang persoalan yang menyebabkan munculnya komplain, pengelolaan komplain, usaha untuk mengatasi hambatan dalam pengelolaan complain; (2) Metode Dokumentasi. Dalam penelitian ini dokumen-dokumen seperti surat-surat, catatan harian, laporan, diambil dari data yang sudah ada pada P5 (Pusat Penanganan Pengaduan Pelayanan Publik) Kota Semarang dan data yang ada pada dinas atau instansi di bawah naungan POKJA (Kelompok Kerja) 1 sampai
POKJA (Kelompok Kerja) 5 di P5 (Pusat Penanganan Pengaduan Pelayanan Publik) Kota Semarang. Metode dokumentasi digunakan untuk memperoleh data-data tentang persoalan yang menyebabkan munculnya komplain. Data dalam wujud dokumen yang akan digunakan peneliti untuk mengetahui persoalan yang menyebabkan munculnya keluhan dari masyarakat adalah data pengaduan mulai tahun 2009 dan 2010 yang ada di P5 dan dinas atau instansi dibawah POKJA 1-5 di P5. Selain itu, dokumentasi juga digunakan untuk melihat tentang tata kerja pegawai P5, prosedur penanganan komplain, hambatan dan usaha dalam pengelolaan komplain, dan lain-lain; dan (3) Metode Observasi. Metode observasi digunakan untuk memperoleh gambaran tentang bagaimana masyarakat Kota semarang melayangkan komplain (keluhan) dan bagaimanan pegawai P5 dan pegawai yang ada pada dinas atau instansi di bawah naungan POKJA (Kelompok Kerja) 1 sampai POKJA (Kelompok Kerja) 5 di P5 (Pusat Penanganan Pengaduan Pelayanan Publik) Kota Semarang dalam merespon dan melayani komplain dari masyarakat.

Untuk menjamin validitas data yang diperoleh, dalam penelitian ini peneliti menggunakan teknik triangulasi yaitu triangulasi sumber dan triangulasi metode.

Analisis data merupakan proses mengorganisasikan dan mengurutkan data kedalam pola, kategori, dan satuan uraian dasar sehingga dapat ditemukan tema dan dapat ditemukan hipotesis kerja seperti yang disarankan oleh data (Meleong, 2002 
; 103). Setelah data yang terkumpul baik yang berasal dari indeep interview (wawancara mendalam) terhadap pegawai P5 maupun dokumentasi, penulis mencoba menginterpretasikan dengan menggunakan metode kualitatif. Analisis data dilakukan sejak awal proses pengumpulan data hingga akhir.

Dalam penelitian ini digunakan analisis data kualitatif dari Miles (1992:16) yang terdiri dari tiga alur kegiatan yang terjadi secara bersamaan, yaitu yang meliputi reduksi data, penyajian data, dan penarikan kesimpulan atau verifikasi.

Reduksi data merupakan suatu bentuk analisis yang menajamkan, menggolongkan, membuat yang tidak perlu dan mengorganisasikan data dengan cara sedemikian rupa sehingga, memudahakan peneliti dalam menarik kesimpulan atau verifikasi.

\section{HASIL DAN PEMBAHASAN}

\section{Deskripsi Pusat Penanganan Pengaduan Pelayanan Publik (P5) Kota Semarang}

Berdasarkan data yang peneliti peroleh, penanganan pengaduan masyarakat khususnya di Kota Semarang dipusatkan di Pusat Penanganan Pengaduan Pelayanan Publik Kota Semarang. Pusat Penanganan Pengaduan Pelayanan Publik (P5) Kota Semarang merupakan lembaga yang dibentuk oleh pemerintah Kota Semarang berdasarkan Peraturan Walikota Semarang Nomor 11 Tahun 2005. Pusat penanganan Pengaduan Pelayanan Publik Kota Semarang (P5) dibentuk berdasarkan pertimbangan bahwa dalam rangka meningkatkan pelayanan, khususnya penanganan pengaduan di tingkat Kota Semarang (Peraturan Walikota Semarang Nomor 11 Tahun 2005). Pusat Penanganan Pengaduan Pelayanan Publik (P5) Kota Semarang beralamatkan di Jl. Pemuda Nomor 148 Gedung Sekretariat di Gd. Moch. Ikhsan lantai 1 Semarang.

Kedudukan Pusat Penanganan Pengaduan Pelayanan Publik (P5) Kota Semarang adalah sebagai lembaga yang membantu Walikota dalam mengkoordinasikan, melaksanakan dan mengendalikan penanganan pengaduan di tingkat Pemerintah Kota (Pasal 2 Keputusan Walikota Nomor 11 Tahun 2005.

Tugas dari Pusat Penanganan Pengaduan Pelayanan Publik (P5) Kota Semarang adalah memfasilitasi, mediasi, menerima, dan mengelola pengaduan serta memantau dan mengevaluasi penyelesaian pengaduan.

Dalam rangka melaksanakan tugasnya, Pusat Penanganan Pengaduan Pelayanan Publik (P5) Kota Semarang sesuai dengan Keputusan Walikota Semarang yang tertuang dalam pasal 4 Keputusan Walikota Semarang Nomor 11 Tahun 2005 tentang Pembentukan Pusat Penanganan Pengaduan Pelayanan Publik memiliki fungsi sebagai berikut:

1. Pelaksanaan, fasilitasi, dan mediasi antara pelapor pengaduan dengan unit kerja pelayanan publik.

2. Pelaksanaan penerimaan dan pengolahan data serta informasi pengaduan masyarakat yang berkaitan dengan pelayanan publik. 
3. Pelaksanaan pemantauan dan evaluasi terhadap penyelesaian pengaduan.

4. Penyampaian hasil tindak lanjut penyelesaian pengaduan kepada pelapor.

5. Pelaksanaan tugas lain yang diberikan oleh Walikota sesuai dengan bidang tugasnya.

\section{Persoalan yang Menyebabkan Munculnya Komplain (Keluhan) dari Masyarakat di Kota Semarang}

Komplain (keluhan) masyarakat di Kota Semarang merupakan bentuk penerapan pengawasan dari masyarakat atau respon ketidakpuasan masyarakat Kota Semarang yang disampaikan oleh masyarakat Kota Semarang baik yang diungkapkan secara tertulis maupun tidak tertulis atas pelayanan administratif, pelayanan barang, dan/atau pelayanan jasa yang diberikan oleh penyedia pelayanan (provider) yaitu penyelenggara pelayanan publik di Kota Semarang. Sehingga komplain (keluhan) masyarakat Kota Semarang merupakan suatu sumber informasi yang sangat penting bagi upayaupaya pihak penyelenggara pelayanan publik di Kota Semarang untuk memperbaiki kesalahan yang mungkin terjadi baik disadari maupun tidak disadari, sekaligus secara terus-menerus menjaga dan meningkatkan pelayanan yang dihasilkan agar sesuai dengan harapan masyarakat Kota Semarang dan sesuai dengan standar yang telah ditetapkan.

Pengaduan yang disampaikan oleh masyarakat baik lewat telepon, surat, datang sendiri, fax, atau yang lewat mas media (Piye Jal Suara Merdeka dan Suara Warga Radar Semarang Jawa Pos) yang masuk di P5 pada kurun waktu JanuariDesember Tahun 2009 adalah 562 pengaduan (Laporan Tahunan P5 Tahun 2009). Sedangkan pengaduan yang masuk di P5 pada kurun waktu Januari-Desember Tahun 2010 adalah sejumlah 718 pengaduan (Buku agenda pengaduan P5 Tahun 2010).

Pengaduan yang masuk di P5 pada kurun waktu 2009-2010 sejumlah 1.280 (seribu dua ratus delapan puluh) aduan. Jumlah aduan tersebut merupakan akumulasi dari pengaduan yang ditujukan pada dinas atau instansi di bawah naungan POKJA 1 (satu) sampai dengan POKJA 5 (lima).

Jenis komplain (keluhan) masyarakat yang ditangani P5 berdasarkan keterangan Bapak A. Puji Raharjo 28 Januari 2011, menyangkut soal: perijinan, pertanahan, lingkungan hidup, ketenagakerjaan, dan pelayanan berupa peningkatan jalan, saluran dan sebagainya.

Mengetahui dinas atau instansi yang sering mendapatkan komplain (keluhan) merupakan hal yang sangat penting. Dengan mengetahui dinas atau instansi yang sering mendapatkan komplain (keluhan) maka pemerintah Kota Semarang dapat mengambil langkah dengan melihat pertimbangan awal bahwa keluhan yang masuk berkaitan dengan apa dan faktor-faktor apa yang menyebabkan keluhan itu muncul. Keluhan yang muncul apakah disebabkan oleh SDM (Sumber Daya Manusia) pemberi pelayanan, kebijakan yang kurang 
responsif, sumber dana yang minim atau yang lainya.

Berdasarkan data yang diperoleh peneliti dapat diketahui bahwa persoalan yang menyebabkan munculnya komplain (keluhan) dari masyarakat di Kota Semarang kaitanya dengan penyelenggaraan pelayanan publik di Kota Semarang muncul akibat dari pelayanan berupa jasa maupun non jasa yang diberikan oleh pemerintah belum sesuai dengan keinginan atau harapan masyarakat. Komplain (keluhan) masyarakat di Kota Semarang muncul disebabkan oleh pihak penyelenggara pelayanan maupun masyarakat di Kota Semarang. Secara lebih rinci ada beberapa persoalan yang menjadi penyebab munculnya komplain (keluhan) masyarakat di Kota Semarang. Hal-hal tersebut diantaranya adalah sebagai berikut:

1. Biaya pelayanan yang tidak wajar

2. Biaya pelayanan yang tidak pasti

3. Pungutan liar (pungli)

4. Kebijakan dan peraturan daerah yang kurang mencerminkan aspirasi rakyat

5. Keberadaan pengamen dan pengemis jalanan yang meresahkan

6. Keberadaan PKL dan warung atau bangunan liar di badan jalan atau bantaran sungai

7. Perijinan (membangun bangunan tanpa izin IMB, usaha dengan memanfaatkan fasilitas perumahan)

8. Sikap petugas pemberi pelayanan

9. Kompetensi petugas pemberi pelayanan
10. Pelayanan yang kurang cepat, jadwal pelayanan yang tidak pasti dan pelayanan yang berbelit-belit

11. Keadilan dalam memberikan pelayanan

12. Kedisiplinan petugas penyedia layanan

13. Tidak ada markah jalan (tanda yang berupa garis-garis penunjuk di tengah jalan) atau ada markah tetapi sudah tidak jelas

14. Keberadaan baliho yang dirasa kurang representatif

15. Keberadaan orang stress atau gila

16. keberadaan PSK (penjajah seks komersial) yang meresahkan

17. Pasangan muda mudi tanpa ikatan suami istri yang meresahkan

18. Parkir becak yang mengganggu pengguna jalan lainya

19. Jalan rusak dan jembatan rusak

20. Air pdam tidak lancar

21. Lampu penerangan jalan mati

\section{Pengelolaan Komplain (Keluhan) Masyarakat dalam Mewujudkan Pemerintahan yang Baik di Kota Semarang}

Dengan adanya otonomi daerah kewenangan daerah untuk mengatur daerahnya menjadi semakin lebar (seperti halnya Kota Semarang). Hubungan antara pemerintah pusat dengan daerah (Kota Semarang) harus sejalan. Secara legal formal pemerintah Kota Semarang terlihat sangat komitmen dalam menanganai keluhan masyarakat. Hal ini terlihat dari norma-norma hukum yang dibuat pemerintah Kota Semarang kaitanya dengan penangan keluhan masyarakat. 
Berdasarkan data hasil penelitian bahwa pengelolaan komplain (keluhan) masyarakat di Kota Semarang di pusatkan pada Pusat Penanganan Pengaduan Pelayanan Publik (P5) Kota Semarang. Penanganan komplain (keluhan) masyarakat di Kota Semarang diatur melalui Keputusan Walikota Semarang Nomor 65/192 tahun 2005 tentang Tata Laksana Pusat Penanganan Pengaduan Pelayanan Publik.

Ruang lingkup pengaduan yang ditangani oleh Pusat Penanganan Pengaduan Pelayanan Publik (P5) Kota Semarang adalah permasalahanpermasalahan yang berkaitan dengan pelayanan publik yang diberikan oleh Pemerintah daerah berdasarkan kewenangan masing-masing SKPD termasuk BUMD.

Sarana prasarana yang diberikan oleh Pemerintah Kota Semarang kepada masyarakat yang ingin menyalurkan keluhanya dapat melalui media yang sudah disediakan. Beberapa media yang disediakan Pemerintah Kota Semarang kepada masyarakat yang ingin menyalurkan keluhanya adalah sebagai berikut: (1) Datang langsung ke sekretariat Pusat Penanganan Pengaduan Pelayanan Publik Kota Semarang yang beralamatkan di Gd. Moch. Ikhsan Lt. $1 \mathrm{Jl}$. Pemuda 148 Semarang; (2) Mengirimkan surat ke sekretariat Pusat Penanganan Pengaduan Pelayanan Publik Kota Semarang yang beralamatkan di Gd. Moch. Ikhsan Lt. 1 Jl. Pemuda 148 Semarang; (3) Melalui telepon (024) 3561717 atau (024) 3588292; (4) Melalui Fax (024) 3588292; (5) Melalui E-mail: penanganan pengaduan@semarang.go.id; (6) Melalui SMS ketik ATLAS<spasi >isi pengaduan kirim ke 9299.

Bagi masyarakat yang ingin melayangkan pengaduan, Isi dari pengaduan harus memenuhi kriteria pengaduan yaitu: (1) Nama pengadu jelas; (2) Alamat pengadu jelas; Permasalahan jelas (merupakan hasil upaya pelayanan pemerintah daerah); dan (4) Bukan merupakan fitnah, surat kaleng dan lain-lain.

Pada dasarnya pengadu harus dapat memberikan informasi sejelas-jelasnya tentang apa yang di adukan, pengadu jelas, dan aduan harus dapat dipertanggung jawabkan. Seperti pernyataan Bapak A. Puji Raharjo pada tanggal 28 Januari 2011 ssyarat yang harus dipenuhi oleh masyarakat jika ingi melayangkan keluhan atas penyelenggaraan pelayanan publik adalah sebagai berikut:

"Nama dan alamat pengadu jelas, keluhan bisa dipertanggung jawabkan, dengan dilampiri bukti pendukung"

Penanganan pengaduan pelayanan publik di Kota Semarang adalah sebagai berikut:

\section{Pengaduan yang Masuk Diterima Oleh Customer Service (CS) untuk Dilakukan Proses Pencatatan Kedalam Buku Agenda}

Dalam rangka tertib administrasi maka pengaduan yang masuk dilakukan pentatausahaan. Wujud pentatausahaan pengaduan yang masuk itu dilakukan proses pencatatan. 
Untuk memudahkan CS mengisi buku agenda dan membuat agenda, pengaduan yang berasal dari mas media sebelum masuk di buku agenda pengaduan di buat kliping terlebih dahulu. Dalam pembuatan klipping, CS terlebih dahulu melihat pengaduan di mas media yang ada ( Piye Jal Semarang Metro) kemudia di gunting dan ditempel pada lembar pembuatan klipping. Setelah aduan di tempel CS, kemudia CS memilah, menulis aduan ditujukan kepada dinas atau instansi mana. Setelah dilakukan pengklipingan aduan baru ditulis di buku agenda.

Setelah dilakukan pengklipingan, selanjutnya CS melakukan pencatatan. Pencatatan dilakukan dengan memasukkan aduan ke dalam buku agenda. hal-hal yang dicatat dalam proses pencatatan aduan adalah menyangkut: (a) Data surat pengaduan; (b) Identitas pelapor; (c) Identitas terlapor; (d) Lokasi kasus; (e)Dalam memasukkan aduan ke dalam buku agenda oleh CS di P5 Kota Semarang adalah mengenai nomor aduan, tanggal masuk, nomor agenda, nama pengadu, alamat/telp, permasalahan, petugas (POKJA), dan keterangan (berisi tentang dinas atau instansi yang dituju berkaitan dengan materi aduan). Untuk pengaduan yang disampaikan lewat surat, fax atau pengadu datang sendiri ke P5 maka CS langsung menulisnya kedalam buku agenda.

\section{Proses Penelaahan Keluhan}

Setelah dilakukan proses pencatatan, pengaduan kemudian ditelaah dan dikelompokkan berdasarkan kode atau jenis masalahnya. Dalam melakukan penelaahan pengaduan di Kota Semarang dikelompokkan berdasarkan jenis permasalahan yang berhubungan dengan hal-hal berikut ini: (a) Penyalahgunaan wewenang; (b) Pelayanan masyarakat; (c) Korupsi/pungli;

Kepegawaian/ketenagakerjaan;

Pertanahan/perumahan;

Hukum/peradilan dan HAM; (g) Kewaspadaan nasional; (h) Tatalaksanan pemerintahan/birokrasi; (i) Lingkungan hidup, dan (j) Umum.

Langkah-langkah yang ditempuh dalam menelaah materi pengaduan masyarakat adalah sebagai berikut: (a) Merumuskan inti masalah yang diadukan; (b) Menghubungkan materi pengaduan dengan peraturan yang relevan; (d) Meneliti dokumen dan/atau informasi yang pernah ada dalam kaitanya dengan materi pengaduan yang baru diterima; (e) Menerapkan hasil penelaahan pengaduan masyarakat untuk melakukan proses penanganan selanjutnya.

Penelaahan pengaduan masyarakat dikelompokkan kedalam dua kategori yaitu pengaduan berkadar pengawasan dan pengaduan tidak berkadar pengawasan.

Apabila telah dilakukan penelaahan atas materi pengaduan masyarakat dan ternyata pengaduan dapat diselesaikan oleh CS maka, CS dapat langsung menyampaikan penanganan pengaduan yang berkaitan dengan materi aduan yang di layangkan oleh pengadu. Apabila pengadu datang langsung ke P5 atau lewat telephone maka CS dapat langsung menyampaikan penanganan pengaduan 
kepada pengadu. Apabila pengadu melayangkan pengaduan selain melalaui telephone atau datang sendiri maka CS menyampaikan penanganan pengaduan sesuai dengan peraturan yang sudah ditetapkan. Apabila pengaduan tidak dapat diselesaikan oleh CS maka pengaduan dinaikkan kepada sekretaris untuk di disposisi sesuai dengan POKJA. Apabila pengaduan dapat diselesaikan oleh POKJA, dapat langsung disampaikan lewat CS kepada pengadu.
Apabila pengaduan tidak dapat diselesaikan oleh CS atau perlu rapat koordinasi, maka pengaduan dari sekretaris langsung dinaikkan ke penanggung jawab P5 atau koordinator P5. Apabila keluhan tidak dapat diselesaikan POKJA maka masing-masing POKJA sesuai disposisi mengetik pengaduan untuk dikirim ke Dinas. Setelah diteliti di paraf oleh sekretaris kemudian ditandatangani oleh penanggung jawab P5/koordinator P5.

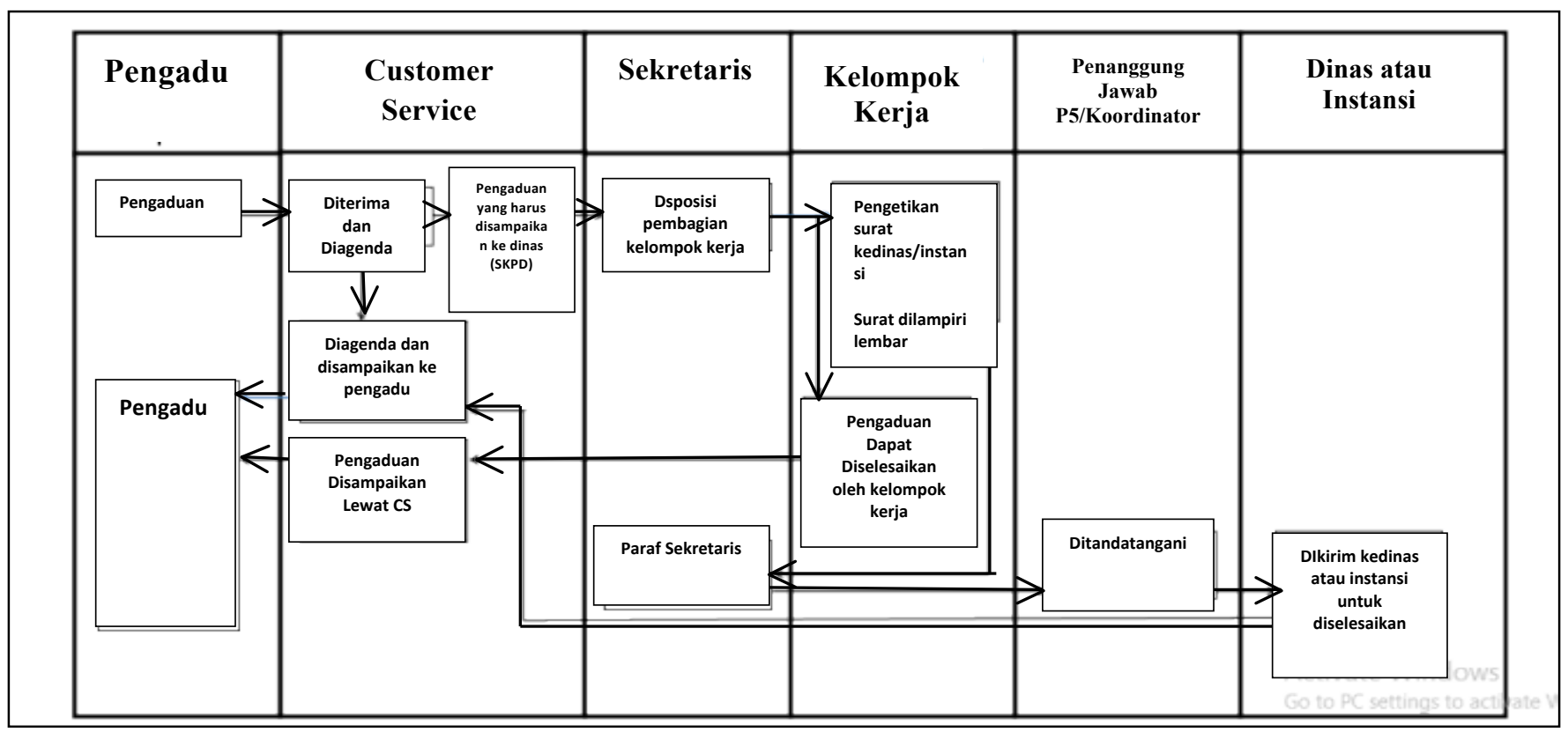

Gambar 1. Model Mekanisme Penanganan Pengaduan Masyarakat Di Kota Semarang

\section{Proses Penyaluran Keluhan}

Penyaluran adalah suatu kegiatan instansi penerima pengaduan masyarakat untuk meneruskan pengaduan tersebut kepada instansi yang berwenang melakukan penanganan, tindakan korektif, dan tindakan hukum lainya sesuai dengan kedudukan, tugas pokok, fungsi dan wewenangnya berdasarkan peraturan perundang-undangan yang berlaku.
Selanjutnya pengaduan dikirim ke dinas/instansi dengan dilampiri lembar jawaban rangkap 2, untuk diselesaikan oleh Tim Penanganan Pengaduan di tingkat Dinas. Setelah diselesaikan di tingkat dinas, pengaduan dijawab pada lembar jawaban pengaduan (dibuat rangkap 2) dikirim ke P5. Lembar jawaban oleh CS 1 lembar disampaikan ke pengadu, 1 lembar untuk arsip P5. 


\section{Pembuktian Atas Kebenaran Substansi}

Apabila dinas atau instansi tidak dapat menyelesaikan pengaduan secara langsung atau pengaduan itu berkadar pengawasan maka instansi atau dinas melakukan telaah lanjutan.

Pengaduan yang berkadar pengawasan diselesaikan dengan melakukan pembuktian atas kebenaran substansinya. Untuk melakukan pembuktian atas kebenaran substansinya dilakukan kegiatan-kegiatan sebagai berikut:

a. Pemeriksaan

1) Telaah lanjutan

Dalam proses telaah lanjutan hal-hal yang dilakukan adalah sebagai berikut:

a) Mempelajari dan merumuskan permasalahan

b) Pemaparan hasil rumusan kepada pimpinan instansi untuk kasuskasus signifikan

c) Merumuskan bahwa pengaduan sudah mengarah kepada adanya pelanggaran terhadap peraturan yang berlaku.

2) Konfirmasi

Yang dilakukan dalam kegiatan konfirmasi adalah sebagai berikut:

a) Mengidentifikasi pelapor

b) Mencari informasi tambahan dari sumber lain yang berkaitan dengan permasalahan yang diadukan sebagai bahan pendukung

3) Klarifikasi

Kegiatan klarifikasi dilakukan sebagai berikut:

a) Meminta penjelasan baik secara lisan maupun tertulis kepada pihak-pihak terkait dengan permasalahan yang diadukan.

b) Melakukan penilaian terhadap permasalahan yang diadukan dengan mengacu kepada peraturan perundang-undangan yang berlaku.

c) Meminta dokumen pendukung atas penjelasan yang telah disampaikan oleh pihak-pihak yang telah dimintakan penjelasan.

Hasil dari telaah lanjutan, konfirmasi dan klarifikasi pengaduan masyarakat adalah berupa kesimpulan tentang perlu atau tidaknya dilakukan pemeriksaan atas permasalahan yang diladukan. Apabila hasilnya menyatakan tidak perlu dilakukan pemeriksaan karena tidak cukup bukti, maka instansi penerima pengaduan menginformasikan hasilnya kepada pelapor.

\section{Pelaporan}

Laporan hasil pemeriksaan disusun secara sistematis, singkat, jelas, dan dapat dipertanggung jawabkan serta memuat kesimpulan dari hasil telaah lanjutan, konfirmasi dan klarifikasi, pemeriksaan dengan data pendukung serta saran tindak lanjut. Hasil pemeriksaan atas pengaduan masyarakat yang disalurkan oleh suatu instansi pemerintah harus dilaporkan kepada pimpinan instansi yang menyalurkan dan APIP daerah. Laporan pemeriksaan yang menyangkut kerugian Negara minimal 1 milyar maka harus disampaikan kepada pimpinan KPK. Hasil pemeriksaan pengaduan harus segera disampaikan kepada pimpinan instansi 
pelapor, pimpinan instansi penerima pengaduan dan walikota.

Penyelesaian hasil penanganan pengaduan masyarakat ditindak lanjuti sesuai dengan peraturan perundangundangan yang berlaku kepada pelapor, terlapor, dan terhadap hasil pemeriksaan.

Penyelesaian hasil penanganan dilakukan baik secara langsung maupun tidak langsung. Secara langsung menyangkut pemutakhiran data, rapat koordinasi, dan monitoring ke instansi yang menangani. Secara tidak langsung dilakukan melalui komunikasi elektronik, dan/atau melalui surat menyurat.

Bukti penanganan adalah laporan hasil penanganan dengan melampirkan bukti pendukung. Status penanganan dikatakan dalam proses jika permasalahan yang diadukan sedang dalam proses penanganan oleh instansi pemerintah yang menerima pengaduan masyarakat. sedangkan status penanganan dikatakan selesai jika:

a. Instansi atau unit kerja yang menerima penyaluran pengaduan masyarakat telah melakukan penanganan dengan bukti yang sah dan dapat dipertanggungjawabkan.

b. Instansi atau unit kerja yang menerima penyaluran pengaduan masyarakat tidak dapat melakukan proses pemeriksaan kebenaran pengaduan masyarakat, karena:

1) Telah dilimpahkan atau ditangani oleh aparat penegak hukum; atau

2) Diluar kewenangan instansi yang bersangkutan dan disalurkan ke instansi yang berwenang menangani; atau
3) Berdasarkan pertimbangan teknis pemeriksaan, terhadap kasus pengaduan masyarakat sudah tidak dapat dilakukan pemeriksaan/ditindaklanjuti.

Koordinasi dalam menangani keluhan masyarakat di Kota Semarang dilakukan baik secara internal maupun eksternal. Koordinasi internal dilakukan antar pejabat/instansi kerja dilingkungan instansi masing-masing, antar pejabat atau unit kerja yang menanganai pengaduan masyarakat dengan pejabat atau unit kerja lain dilingkungan instansi tertentu. Koordinasi eksternal dilakukan antar pejabat APIP (Aparat Pengawas Intern Pemerintah) dan/atau yang menangani pengaduan masyarakat, antar pejabat APIP dengan aparat penegak hukum, anatar pejabat APIP dengan masyarakat dengan organisasi masyarakat. koordinasi eksternal dapat dilakukan dengan membuat Surat Keputusan Bersama (SKB) anatar APIP, aparat penegak hukum, pejabat pemerintah yang terkait dan masyarakat atau ORMAS (Organisasi Masyarakat).

\section{Pengarsipan}

Pengarsipan dilakukan untuk mempermudah dan mempercepat pencarian kembali dokumen pengaduan bila sewaktu-waktu diperlukan.

Pada perkembangan terakhir Pemerintah Kota Semarang dalam rangka komitmen dalam pelayanan publik, Pemerintah Kota Semarang memandang bahwa pengaduan masyarakat merupakan salah satu bentuk partisipasi pengawasan 
masyarakat yang efektif dalam rangka ikut serta mewujudkan penyelenggaraan pemerintahan yang baik bebas kolusi, korupsi dan nepotisme. Pada perkembangan terakhir Pemerintah Kota Semarang menetapkan Peraturan Walikota Semarang Nomor 16 Tahun 2010 tentang Pedoman Penanganan Pengaduan Masyarakat Bagi Unit Kerja di Lingkungan Pemerintah Kota Semarang.

Pedoman penanganan pengaduan masyarakat bagi unit kerja di lingkungan Pemerintah Kota Semarang dimaksudkan sebagai acuan bagi unit-unit kerja di lingkungan Pemerintah Kota Semarang termasuk BUMD agar dalam penanganan pengaduan masyarakat dapat lebih terkoordinasi, efektif, efisien dan dapat dipertanggungjawabkan kepada masyarakat. Dengan adanya pedoman penanganan pengaduan diharapkan pengaduan masyarakat dapat dengan ceepat dan tepat ditangani dalam rangka mendukung terwujudnya pemerintahan yang baik (Good Governance) dan bebas dari korupsi, kolusi dan nepotisme (KKN).

Ruang lingkup pedoman penanganan pengaduan masyarakat bagi unit kerja di lingkunag pemerintah kota semarang menyangkut; 1) penanganan pengaduan masyarakat yang diterima instansi pemerintah kota termasuk BUMD ; dan 2) Mengatur sikap, tindakan, ucapan dan perilaku aparatur negara yang menangani pengaduan masyarakat.

Dalam menyelenggarakan penanganan pengaduan masyarakat setiap instansi wajib berpedoman pada asas-asas penanganan pengaduan masyarakat. Adapun azas-azas tersebut adalah; 1)
Kepastian hokum; 2) Transparansi; 3) Koordinasi; 4) Efektivitas dan efisiensi; 5) Akuntabilitas; 6) Obyektifitas; 7) Proporsionalitas; dan 8) Kerahasiaan.

Sebagai pedoman bagi aparatur pemerintah yang menangani pengaduan masyarakat dalam bersikap, bertindak, berucap dan berperilaku agar memiliki moral dan kepribadian yang baik, mendorong etos kerja serta menumbuh kembangkan dan meningkatkan kepercayaan masyarakat dalam penanganan pengaduan masyarakat maka pemerintah kota semarang menyusun etika dalam penanganan pengaduan masyarakat (lampiran Walkot Semarang Nomor 16 Tahun 2010).

Etika tersebut berisi hal-hal sebagai berikut; 1) Nilai-nilai dasar pemerintah yang menangani pengaduan masyarakat; 2) Kewajiban dan larangan bagi aparatur pemerintah yang menangai pengaduan masyarakat; 3) Waktu Penyelesaian Pengaduan masyarakat harus dapat diselesaika maksimal 90 hari setelah surat pengaduan diterima kecuali ada alasan yang dapat dipertanggung jawabkan; dan 4) Perlindungan terhadap pelapor dan terlapor.

Selama proses pembuktian pengaduan, instansi/unit kerja yang berwenang menangani pengaduan masyarakat wajib memberikan perlindungan hukum dan perlakuan yang wajar baik kepada pelapor maupun terlapor. 


\section{Usaha untuk Mengatasi Hambatan dalam Pengelolaan Keluhan Masyarakat di Kota Semarang}

Untuk menampung segala aspirasi masyarakat, dalam rangka untuk memperbaiki pelayanan yang baik kepada masyarakat tentu sangat penting sekali keluhan dikelolah dengan baik, benar dan tepat.

Kota Semarang memiliki wilayah yang cukup luas dan memiliki karakteristik masyarakat yang berbeda-beda. Warga masyarakat ada yang berpendidikan tinggi dan ada yang rendah. Masyarakat Kota Semarang ada yang sudah melek teknologi dan juga ada yang belum. Lokasi Kota Semarang ada yang mudah dijangkau dan juga ada yang agak sulit dijangkau. Warga masyarakat Kota Semarang memiliki pekerjaan yang berbeda-beda. Sehingga dalam menangani keluhan dari masyarakat yang berbeda-beda karakternya, yang berbeda-beda kebutuhannya tentu tidak luput dari halhal yang menghambat penanganan pengaduan.

Hal-hal yang dapat menghambat penanganan pengaduan adalah Informasi yang tidak jelas sehingga membuat aduan tidak dapat diproses. Misalnya data pengadu tidak jelas, nomor telepon pengadu tidak dapat dihubungi dan lainlain. Sehingga menghambat koordinasi petugas yang menangani pengaduan kepada pihak pengadu. Pengaduan dalam bidang pendidikan sebagai berikut berupa pengadu sering tidak dapat dihubungi. Sebab yang mengadu dimungkinkan adalah orang tua siswa yang memiliki anak sekolah. Hal ini mungkin dikarenakan orang tua juga kuwatir akan berimbas kepada anaknya. Pihak teradu juga jika ditanya tidak pernah melakukan pemungutan biaya.

Kurangnya responsivitas dari SKPD teradu untuk dimintai koordinasinya terkait dengan pengaduan yang masuk di P5. Hal ini disebabkan karena masih adanya beberapa dinas atau instansi yang kurang tanggap terhadap adanya pengaduan.

Apabila ada dinas atau instansi yang kurang responsif, tindakan yang dilakukan oleh P5 adalah apabila ada pengaduan yang tidak menjadi kewenangan pemerintah kota, tapi di laporkan ke P5. Sehingga untuk mengatasi hal tersebut yang dilakukan adalah menjalin koordinasi dengan instansi diluar pemerintah kota agar agar menyampaikan atau menyelesaikan keluhan masyarakat. Jika dinas kurang responsif maka P5 memberitahu kepada instansi terkait untuk menanggapi atau diadakan rakor penyelesaian permasalahan.

Kurangnya sumberdaya manusia pemberi pelayanan baik itu pada tataran front line maupun dibagian proses perijinan dinas/instansi. Hal tersebut terlihat dari keluhan yang dilayangkan ke masyarakat. misalnya masyarakat ragu dengan kemampuan petugas yang melayani.

Selain itu, yang juga menghambat penanganan pengaduan di Kota semarang adalah terbatasnya sarana dan prasaranan penunjang penanganan pengaduan berupa kendaraan roda dua (laporan P5 Tahun 2009). Sehingga ketika ingin 
menggunakannya masing-masing POKJA harus bergantian.

Tidak semua masyarakat tahu dimana penanganan pengaduan pelayanan publik Kota Semarang. Sehingga tidak adanya pengaduan yang masuk di beberapa dinas/instansi yang ada tidak dapat dijadikan indikator bahwa pelayanan yang diberikan kepada masyarakat sudah baik. Agar masyarakat dapat melayangkan pengaduannya dengan benar dan pada dinas atau instansi yang tepat, maka P5 mengadakan sosialisasi penanganan pengaduan pelayanan publik Kota Semarang kepada masyarakat. Misalnya sosialisai yang dilakukan P5 bidang pendidikan dengan peserta kepala sekolah SD, SMP, SMA, dan kepalah UPTD se Kota Semarang.

\section{KESIMPULAN}

Berdasarkan hasil penelitian dapat peneliti simpulkan bahwa: (1) Persoalan yang memunculkan keluhan adalah disebabkan karena pelayanan baik jasa maupun non jasa dari penyedia pelayanan (pemerintah Kota Semarang) belum sesuai dengan harapan masyarakat. Selain itu, keluhan muncul disebabkan karena penyedia pelayanan maupun pengguna layanan yang melanggar hak pegguna layanan yang lain. (2) Pengelolaan keluhan masyarakat khususnya di Kota Semarang dipusatkan untuk ditangani oleh P5 (Pusat Penanganan Pengaduan Pelayanan Publik) Kota Semarang. Masyarakat dapat menyalurkan keluhan melalui media cetak, elektronik dan atau datang langsung ke P5. Penanganan keluhan dilakukan dengan melalui proses sebagai berikut: (a) Pengaduan yang masuk diterima oleh Customer Service (CS) untuk dilakukan proses pencatatan kedalam buku agenda; (b) Proses penelaahan keluhan; (c) Proses penyaluran keluhan; (d) Pembuktian atas kebenaran substansi keluhan; (e) Pelaporan; dan (f) Pengarsipan. Namun, cepat atau lambatnya pengaduan dapat ditangani lebih banyak ditentukan oleh dinas atau instansi yang diadukan. (3) Hal yang menghambat dalam penanganan pengaduan adalah adanya pengaduan yang tidak jelas, kurang responya SKPD teradu untuk dimintai koordinasi, kurangnya SDM yang handal, kurangnya sarana dan prasarana. Usaha untuk mengatasinya dalah dengan melakukan sosialisasi tentang pusat penanganan pengaduan pelayanan publik Kota Semarang kepada pengguna layanan menyangkut bagaimana melayangkan keluhan yang baik, benar dan tepat. Disusunya pedoman penanganan pengaduan pelayanan publik bagi unit penyedia layanan di Kota Semarang.

Saran yang peneliti ajukan dalam penelitian tentang penanganan (komplain) keluhan masyarakat dalam mewujudkan pemerintahan yang baik di Kota Semarang adalah sebagai berikut; (1) Dengan ditemukannya banyak persoalam yang menyebabkan munculnya keluhan masyarakat di Kota Semarang pada penelitian ini, maka kajian akademis secara terpadu dari berbagai disiplin ilmu perlu dilakukan; (2) Perlu adanya sosialisasi dan penyampaikan informasi secara terus menerus mengenai 
keberadaan P5 kepada masyarakat pengguna layanan maupun penyedia layanan; dan (3) Melihat pentingnya memperhatikan dan mengelola keluhan dari masyarakat untuk memperbaiki kualitas pelayanan publik yang lebih baik. Maka, setiap penyelenggara pemerintahan perlu memperhatikan keluhan dari masyarakat.

\section{PENGHARGAAN}

Ucapan terima kasih penulis sampaikan kepada pihak-pihak yang ikut serta mulai dari penelitian hingga publikasi artikel ini:

a. Lembaga Penelitian dan Pengabdian Kepada Masyarakat (LP2M)

Universitas Negeri Semarang yang telah memberikan dana bantuan (Dana DIPA) untuk melakukan penelitian ini.

b. Pemerintah Daerah Kota Semarang, KESBANGPOLINMAS kota semarang yang telah mengizinkan peneliti untuk melakukan penelitian di Kota Semarang.

c. Program Studi PKn Universitas Pamulang yang bersedia menerbitkan artikel hasil penelitian ini.

d. Serta berbagai pihak yang tidak dapat saya sebut satu-persatu. Semoga artikel ini menambah kazanah ilmu pengetahuan serta menjadi salah satu referensi ilmiah dibidang akademik. Serta menjadi salah satu rujukan organisasi public maupun swasta dalam menangani keluhan dari masyarakat.

\section{REFERENSI}

Arif, S. (2008). Paradigma Pelayanan Publik. Dalam Saeful Arif (ed) Reformasi Pelayanan Publik. Malang: PLaCIDS dan Averroes Press.

Inpres No. 1 Tahun 1995 tentang Perbaikan dan Peningkatan Mutu Pelayanan Aparatur Pemerintah Kepada Masyarakat

Keputusan Menpan No. 63/KEP/M.PAN/7/2003 tentang Pedoman Umum Penyelenggaraan Pelayanan Publik

Keputusan Menteri Negara Pendayagunaan Aparatur Negara Nomor PER/05/M.PAN/4/2009 tentang Pedoman Umum Penanganan Pengaduan Masyarakat Bagi Instansi Pemerintah

Monier, A.S. (2001). Manajemen Pelayanan Umum di Indonesia. Jakarta: Bumi Aksara.

Rahmayanti, N. (2010). Manajemen Pelayanan Prima. Yogyakarta. Graha Ilmu.

Rosyada, D., dkk. (2005). Demokrasi Hak Asasi Manusia Dan Masyarakat Madani Tim Ice Uin Jakarta. Jakarta: Kencana Prenada Media Group.

Suandi, I. W. (2010). Eksistensi Kebijakan Publik dan Hukum Dalam Pemerintahan Daerah. Jurnal Ilmiah Fakultas Ilmu Sosial dan Ilmu Politik Universitas Udayana bali. Vol. I No. 01, Tahun 2010.

Sutomo, dkk. (2007). Manajemen Sekolah. Semarang. UPT Percetakan dan Penerbitan MKK UNNES PRESS. 
Jurnal Pendidikan Kewarganegaraan,

Vol. 4, No. 2, September 2017
Available online at http://openjournal.unpam.ac.id/index.php/PKn

Suyahmo. (2009). Relevansi Etika Aristoteles dengan Etika Pancasila. FIS (Forum Ilmu Sosial). Volum 36 No. 2 Desember 2009.

Undang-Undang No. 25 Tahun 2009 tentang Pelayanan Publik.

UUD 1945 (Amandemen ke empat)

Qudrat-I, K. (2009). UNDP On Good Governance. International Journal of Social Economics. Vol. 36 No. 12, halaman 1167-1180 www.emeraldinsight.com/0306-

8293.htm. Diakses pada tanggal 11 Januari 2011. 
[ halaman ini sengaja dikosongkan ] 